\title{
The Balance Sheet of Western Philosophy in This Century
}

Roger Garaudy*

Today, Western philosophy is all too close to its origins because it has never really answered the questions that brought about its birth. These questions are: What is the meaning of life and death? What is the source and what is the vocation of our freedom? How to act in order to fulfill the patterns of God? Such essential questions of philosophy are raised only by man, and properly so. For only man cannot live without raising them.

In nature, every being has a place and a function which are not of his own choosing. Every creature is subject to the law of God: a stone must fall when released, a plant must grow when nourished; an animal must follow its instinct. All of them obey and fulfill this divine law without choice or questioning.

With man, however, a new realm begins. He is the only creature that God has endowed with the choice of either disobeying or fulfilling that law after a free, deliberate, and responsible decision.

The Holy Qur'an says: "We have offered Our trust to the heavens, to earth and mountains. But they all rejected it in fear and trembling. Only man arose to accept and carry that trust. He alone is unjust and ignorant (33:72).

It was thus that human history began, a history which man himself makes, unlike all other creatures which fulfill the law of necessity.

In order to regain this lost unity, that is to say, in order to integrate him into the whole of creation, and thus give his life and death their place and meaning in the divine order, man created all sorts of myths. But he also received divine assistance through the revelations brought by the prophets of every people.

In the sixth century after Christ, throughout Asia, the great myths of Mesopotamia and Egypt, the wise sayings of the Upanishads of India, and those of Chinese Taoism raised and considered the basic problems of the ultimate reality of this world, its meaning and significance, our role in it,

\footnotetext{
* Roger Garaudy is a prominent French Muslim who has written extensively on a number of issues. His paper was originally presented at the Third International Seminar on the Islamization of knowledge organized by the International Institute of Islamic Thought at Kuala Lumpar, Malaysia, July, 1984.
} 
and our possible action.

It was man's first attempt to reach a satisfactory answer to the question of relations between man and nature, between man and God. In the Near East, where the great revelations of the Book of God had taken place, in which the divine answers to the human questions were given, the sages deliberated over the basic problems with great concentration.

One of those sages, Heraclitus, had already proclaimed in the sixth century B.C. that

"All things are one."

"The Law is to follow the will of the One."

"Wisdom consists in a single thing only, namely: to know the thought which governs and orders everything."

Similarly, the Hanifs had come very close to these answers in their search for the will of God.

Under these circumstances came the first "secession" (withdrawing) of the West. Consuming involvement in trade had caused man to lose contact with nature, nature being cultivated through slaves. Likewise, the fierce commercial competition between the cities, and between the citizens of each city, caused men to lose sight of the divine unity.

It was then the fashion to deny any absolute, to assume man's self-sufficiency, and to proclaim him "the measure of all things." By rejecting both transcendence and community at once, human society was turned into an arena of confrontation between individuals and groups driven by their will to growth and their will to power.

The first philosophers of the West, the Sophists of Athens, gave us the first formulation of this moral. "The good," they said, "consists in having the strongest desires as well as the means to satisfy them." Obviously, this law of the jungle continues to this day to characterize Western societies bent upon growth as well as maintaining "the balance of terror."

Such was the birth of philosophy in the West in the fifth century B.C. It was an occasion which prompted Socrates to seek new foundations for moral knowledge which, he thought, might save man from the impending chaos and downfall of Athens, from its total moral disintegration. As he saw it, the problem was one of finding a principle for making value judgements; a principle that was viable enough to withstand the array of happenstance answers given by the Sophists.

One of Socrates' disciples, Plato, in pursuit of the same objective, elevated the search for knowledge of virtue and politics to a science. But that science, in his view, consisted of relating reasons and concepts together in necessary, unbreakable bonds.

This conception of science leaves no room whatsoever for faith, which was relegated to a position of inferior knowledge. Nor does it leave any room for 
love. For what is called "Platonic love" is not the love of other persons but of an intellectual search for a total truth. Nor does it leave any room for beauty. Indeed, Plato chased the poets out of his ideal Republic because their creative imagination was deemed by him to be a menace to the established order.

This reductionist conception of reason, which deprives man of his noblest dimensions (faith, love, beauty) radically separated the soul from the body, the sensory from the intelligible. And this is still the most salient characteristic of Western philosophy.

It is a kind of lame rationalism, this Greek philosophizing, which robs man of his essential dimensions, of love, of beauty, and of faith. The philosophy's dualism of soul and body, of the sensory and the intelligible, has brought sterility to Western thinking since Plato and Aristotle. Moreover, it impoverished religion by pretending to bring it within the framework of Greek philosophy, as it did with Judaism at the hands of Ibn Maymūn (Maimonides), with Christianity through St. Thomas Aquinas, and with Islam in the hands of Ibn Rushd.

There was a time when the West might have cut itself loose from this reductionist conception of reason. That moment came when, from the Muslim University of Qurtubah from the tenth to the thirteenth centuries, a new vision shone over Europe. In this Islamic view, reason in its full dimensions was being taught and advocated.

First, the natural sciences cultivated the experimental method and, through it, enabled Arab-Islamic thought to break away from the speculative thinking of the Greeks. When that science moved to the European Middle Ages, it degenerated into scholasticism. The Islamic experimental and mathematical sciences enabled the Muslims to discover a new order of relations between things within the chains of necessary causality.

Islamic philosophy, which studied purposes as against science which studies causes, was able to establish, in line with Qur'anic teaching, the role of every object and every event as a sign of divine presence and action. Islamic philosophy was able to institute a way of thinking that regained for life its meaning and purpose by means of determining things and events as happenings in a divine scheme.

Third, faith was understood by Muslims not as a limitation of either science or wisdom; on the contrary, faith worked their continuation and perfection. By moving from cause to effect and from effect to a new cause, science could never reach a first and satisfying cause. Likewise, philosophy, by moving from end to end and purpose to purpose, could never arrive by itself to a final end or purpose. Both demand for their proper exercise the presence of faith, that they may know their proper limits. In this sense, faith could well be the culmination of science and wisdom, given the axioms and postulates of scientific and moral inquiry. Indeed, faith is reason without frontiers or limits.

In the face of these breakthroughs of the Muslims, the West made another 
secession instead of following the new light provided by Islam. This retreat of the West was marked by Bacon, Descartes, and Auguste Comte.

Roger Bacon, who is regarded in the West as the father of the experimental method in the natural sciences, admitted that his major work and achievement was borrowed from a translation of the Optics of Ibn al Haytham, who taught the subject at Qurtubah. However, he separated experimental science from the Islamic legacy of learning, which included morality and faith as well.

Likewise, Descartes proclaimed unequivocally that one must separate the problems of morality and faith from the domain of reason. In his truncated view of reason, ends or purposes and transcendence have nothing to do with reason. In his twenty-eighth meditation, he wrote that it is futile to ask the question why God did a certain thing. One should only ask how He did do it? Since Descartes, the West has stopped asking why questions. Its interest is solely in the how. How to make an atom bomb? Never, why should one make an atom bomb?

As to transcendence, it has lost its reason and ground when one pretends that existence has for ultimate evidence the proposition "I think, therefore I am," and that the existence of any object will have to come at the tail end of a process of reasoning that moves from that base through a chain of deductive syllogisms. Indeed, transcendence is lost forever when through a contemptuous ontological proof of God, one claims that one can deduce the existence of all real things - including God - by arguing from the reality of thought to a presumed reality of being. Revelation and its whole claim for faith thus becomes futile and useless when the existence of God could be the conclusion of logical reasoning.

This line of Western thinking led to the positivism of Auguste Comte. Positivism, or the denial of reality to anything not perceived through the senses, or not measurable by mathematics, has become the tacit postulate of all that goes under the name of "modern science" or "Western science." This attitude has unfortunately pervaded all the human sciences (the humanities and social sciences) since Comte as well. All of them rest on the ultimate premise that man is just another object of nature, not unlike the objects which physics, chemistry, and biology study.

The postulates of this positivism are three:

1. Every scientific truth, being an exact and definitive copy of natural reality, precludes that any of the fundamental notions of science be subject to doubt. Progress of knowledge is hence an accumulation of these truths.

2. Every reality, whether natural or human, is susceptible to be studied by one and the same method, of which physics and mathematics are the ideal paradigm.

3. It follows that all problems, including those of morality, politics, and society, can indeed be solved by the same method. 
With these postulates, science has become scientism, technology has become technocracy, and politics has become Machiavellianism.

The disadvantages of this positivistic conception of science become especially exacerbated when the method is applied to the sciences of man. They are not sciences since they take no account of the specificity of their object. They apply to man the methods that fit the knowledge and manipulation of things.

A typical example of this bungling is the discipline of Western economics. It is not a science but an ideology of justification of a given social system which regards man as if he were an animal. The so-called classical economics taught in all the universities of the West, and unfortunately elsewhere as well, hides behind mathematical equations its fundamental axiom. This axiom is that man is merely a producer and consumer of goods and that man is moved solely by his individual self-interest. This Western notion of man as homo economicus is the diametrical opposite of the notion of man in Islam. Whenever we send our sons and daughters to study in the West, we send them unknowingly to learn militant atheism. For it is not possible to treat economics scientifically when one abstracts man and denudes him of his specificity, of his transcendent dimension, of his morality and values. To give our students intellectual armament with which to defend themselves against this sad state of knowledge at the present time is what Isma'il al Farūi calls "Islamization of the disciplines."

In fact, all the mutations of the twentieth century demonstrate the false premises and postulates of Positivistic Science. In the natural sciences, the changes in physics since the emergence of the relativity and quantum theories have rendered questionable all the conceptions, once held eternal and necessary, of space and time, of determinism, of the relation of matter to energy, of the subject to the object of knowledge.

In politics, that is, in history in the making, atomic weaponry and the invasion of space, on the one hand, and the end of colonialism, on the other, have rendered questionable all the values that were once necessary and untouchable in that domain. Equally questionable have become the values of nations and armies, of order and revolution, indeed, of the whole West with its progress, its hegemony, and the false universalism of its culture.

The double accomplishment of atomic armament and the conquest of space has given birth to the "absolute weapon," that is to say, to the possibility of hitting any objective with missiles fired from any base on earth, or to that of destroying the earth and all life with the present stockpile of weapons equaling one million times the bomb dropped on Hiroshima.

The disequilibrium is growing, indeed it has become prodigious, between the United States and Europe, where meat and butter are kept in cold storage, and a so-called Third World where millions of humans are dying of starvation and malnutrition. 
These are only two examples, among many, that prove that surrender to the logical implications of Western culture or to its peculiar brand of growth and development after five centuries of Western hegemony does lead and had led the entire planet Earth to the brink of suicide.

Islam can bring to the world a different future, as it did to Qurtubah and Madinah. It can do so through its eternal message of transcendence and ummah. In fact, Islam is the only faith capable of effectively countering the fatal implications of Western dominion. Against positivism, it gives us transcendence; against individualism, it gives us the ummah.

Today, Islam has opportunities for spreading far greater than those it enjoyed at its height in the seventh and eighth centuries. But Islam must be presented not as a religion among others. Rather, it must be seen as the point of convergence of the faith that upholds the world, as the climax of all forces leading toward that ideal faith.

Islam did not conquer the world by military feats. Rather, it achieved its glorious victory over the world through a cultural revolution which gave a new purpose for living and a new life to the human masses populating the distintegrating empires of those days.

The Prophet (ȘAAS) never claimed that he was creating a new religion. Rather, he called all humans to submit to God as the Hanifs of old did, beginning with Adam, the first human and the first Prophet, with the purpose of actualizing the Divine plan on earth.

When God sent those early messengers for the purpose of showing mankind "the straight path," He chose men capable of reaching and convincing the millions. He did so by treating every culture on the level and in the language proper to it. Allah (SWT) did not send doctors of law or philosophers to convey the message - neither an Ibn Maymun, nor an Ibn Rushd, nor a St. Thomas Aquinas. He sent a shepherd like Amos, a carpenter like Jesus (AS), an illiterate tradesman like Muhammad (ȘAAS). Nor did He charge them with conveying the complete science of an encyclopedia. God sent His messengers to all men, including the ignorant, to teach the meaning of life, to call for submission to the plans and patterns of God, to exercise their responsibility as God's vicegerents (Khilafah) on earth.

Primordial Islam has known well how to integrate the cultures of all peoples, from Byzantium and Greece to Persia and India. It did so in a creative and selective manner, yet critical of all that did not agree with itself. In this century, living, dynamic Islam must do likewise. We, the Muslims, ought to exercise the same creative effort as did our ancestors.

As far as the natural sciences are concerned, the problem today is that of the "transfer of technology". These transfers are never as innocent as they look. Often, they bring into the Muslim world the life and thought styles of the West. And in all cases, they help perpetuate Muslim dependence upon the 
West, upon the West's research centers, upon its experts and professional cadres. They determine the future course of Muslim development, and make Muslim countries dependent upon the West's philosophy underlying Western science and technology.

Hence it is crucial, in this as in other domains, to avoid two errors: blind copying of the West and outright rejection of everything Western. We should acquire Western science and technology selectively, creatively, and critically.

First, our adoption must be selective. The countries of the West developed their science and technology in satisfaction of their own peculiar needs, in their own historical circumstances and style of living. These are not the same on other continents of the world. It is not evident, for example, that in industrial technology the greatest priority must always be accorded to the economizing of labor resources. Likewise, in the fields of medicine and pharmacology, Western peoples have their own rhythms of life and their own habits of feeding. These particular conditions dictate that in the West priority be assigned to cardiovascular diseases, just as the nervous tensions and breakdowns which Western life presents demands tranquilizers. In areas where the majority of the population is constantly undernourished and lives on the land as farmers, medical and pharmaceutical research, as well as hospital needs, are obviously different.

Second, our adoption of science and technology must be critical. Transfer of technology always implies a tacit adoption of modes of living and thinking, of the mentality of development, the philosophy of positivism, which is the antidote of faith. It brings in its trail an individualism destructive to the social fabric of the ummah. This phenomenon is more obvious when the matter imported into the Muslim world consists of films and television series, of books and other publications. Let us remember that Hollywood does not constitute modernity but decadence. It is the disintegration of life. It is not by accident that those countries that are the most "developed" and the richestlike the United States and Sweden-have the highest incidence of teenage suicide. Those countries where people seek death because they have no reason to live, would they be the educators of mankind?

When I travel through the Maghrib cities still under the influence of French culture, it upsets me when people ask me for information about Western existentialists, Western structuralists, the so-called new philosophers, who have absolutely nothing to contribute to the future of humanity.

Let us repeat it once and for all: Modernization is not Westernization. This does not mean that we Muslims have nothing to learn from the West. For example, when a Muslim learns from Immanuel Kant and his disciples that all that he says about God, nature, man, and history is something human, susceptible to criticism and revision, something that must be relative and conditional, that Muslim has learned a major truth about humanity. This truth 
is the other side of another truth which Muslims have contributed to humanity, namely, that although it is God Himself who dictated the Qurän, it is nonetheless humans who read, understand, and comment upon it. Their word can never be of the same status as His word. Humans are the products of history, of their problems and needs, of their time and environment. It is therefore always a difficult task to distinguish what is divine and eternal from what is human and relative.

Third, our adoption of Western science and technology must be creative. Wholly new branches of scientific and technological development should arise out of the specific needs of each country or region, and be fed by its own local resources. Whether it be a matter of energy resources, or the artificial production of foodstuffs for animal growth, the United States' monopoly on these industries must be broken.

It is hence not necessary, for the da'wah of Islam to succeed in the modern world, that we should produce a new "philosophy." For such would entail the risk of producing a philosophy not unlike that of the Middle Ages, one borrowed from the Greek tradition, or one following the lines of Christian systematic and scholastic theology.

Nor is there any need for us to produce one commentary after another, without end, on books of law that were designed to solve the social problems of a former epoch. At any rate, there is nothing, in the old books, to prevent us from making our own creative and fresh contribution.

In my humble opinion, the major task confronting us Muslims today is to rediscover the majestic simplicity of the message of Islam; to present it to the new century in compensation for all the wealth of values that the West had caused humanity to lose. We must recapture, for the benefit of future generations, the conviction of Islam that the world and history do have meaning and constitute a single unity. It is indeed the personal responsibility of each one of us to witness unto this meaning and unity by our unconditional submission to the call of Allah (SWT), just as Sayyidina Ibrahim (AS) did.

As far as philosophy is concerned, the central problem for Muslims today is not the integration into the Islamic view of the philosophy of Aristotle and the Greeks, which in the past had swayed the Muslims from the straight path, nor of that which has dominated the modern West since the Renaissance, which has only deepened man's doubt of his own significance and even driven him to despair.

On the contrary, the Muslim thinker today needs to learn from Western philosophy nothing but its critical methodology which is really its essential core from Socrates to Galileo, from Kant to Husserl. The Muslim thinker needs to go back to the period of the first "secession" of the West (the sixth century B.C.E.) when human thought first posed the fundamental issues of life: 1 . the relation of man to God, to other men, and to nature; and 2. the 
meaning and purpose of life, of death, of history, of the necessary significance that attaches itself to them because they are the acts and dispositions of Allah (SWT). Such science, philosophy, and wisdom never preclude revelation or our need for same. On the contrary, they invoke and demand it to specify both their axioms and their limits.

In loyalty to their highest traditions, the faith and culture of Islam cannot isolate themselves from the world out of fear to learn from others. This can only bring division and narrow-mindedness. Indeed, the faith and culture of Islam will be enriched and modernized not only by their openness to the West but to all that is human and universal.

Let us come to our final and essential point. We do not wish for Islam to be presented as one religion among many. Rather, we must seek to present it as the primordial religion ("al Din," not simply "Din"), the culmination and apogee and conclusion of all other revelations. Allah (SWT) has ordered us in the Qu'rān to honor all prophets. The message the Muslim is expected to convey to the People of the Book, for instance, which enjoys a tremendous penetrative power, testifies to his understanding of and respect for the earlier revelations. It should always show the culmination of that tradition of divine revelations in Muhammad (ȘAAS).

This knowledge of the other religions is for us Muslims a duty. In the lands of Asia and the Near East, how could any Muslim be a stranger to the Vedas and Upanishads, to the first sages of Taoism, to the teachings of the Buddha, of Heraclitus and Zoroaster, of Jeremiah and Jesus? How could he fail to command such mastery of the origins, of how the divine messages were corrupted and falsified by their followers; or of how the Qurann preserved for the benefit of mankind all the best that those earlier messages had contained? Indeed, how could the Muslim fail to present the fact that the Quraanic revelation developed the seeds of earlier revelations to their fullest perfection?

The greatest dangers, for Muslim thinkers today, is to succumb to a false sense of self-sufficiency, of triumphalism, of self-isolation. The certainty and conviction of the truth of our faith should not be a product of our ignorance of others, but rather of our full knowledge of them.

If we can avoid these dangers, the conversion of a non-Muslim to Islam will not seem to him as a lapse from his past and traditions but as their very culmination and realization. This is the first condition of viability of our da'wah: to impart to each an awareness of this living continuity of divine revelations and religious life.

The second condition is to prove ourselves capable of solving the problems which the West is incapable of solving. We need to discover new forms of growth and development, a culture that does not lead to human destruction but to the flowering of humanity.

For this, it is of capital importance not to read the words of God in the 
Qurann with the eyes of the dead, that is to say, with the eyes of those who may have found the straight path but went no further than to solve the problems of their own time and localities. We must read the Qur'ann and with eyes fixed on the solution of our problems, and with minds and wills determined to discharge our responsibility as the vicegerents of Allah taala on earth. We must, in short, find answers to our own problems in light of the eternal message of the Qur'ān.

To be faithful to our ancestors is not to preserve the ashes of their fire but to transmit its flame. 